\title{
Terrestrial Gastropods: Survey and Relationships between Land Snail Assemblage and Soil Properties
}

Fadia N. Heiba ${ }^{1}$; M. M. Mortada ; S. N. Geassa ${ }^{1}$; A. I. Atlam ${ }^{1}$ and Sahar I. Abd El-Wahed ${ }^{2}$

${ }^{1}$ Faculty of Science, Tanta Univ.,

${ }^{2}$ Plant Protection Research Institute, ARC, Dokki, Giza.

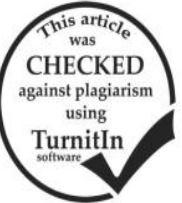

\section{ABSTRACT}

Terrestrial gastropods (snail and slug) species were studied concerning their occurrence survey and population density in 25 localities representing five districts of Kafr EL-Sheikh Governorate, during September 2015 to August 2016. An attempts to obtain basic information concerning their relationships between land snail species assemblage and soil properties .Ten herbivorous species, eight land snails and two land slugs' species belonging to three families Helicidae, Succinidae, Limacidae of order Stylomatophora were found on different crops. Population density of Land snails and slug species varied in their incidence and level of infestation according to each locality and host type. Soil samples were taken from five districts due to analytical chemically and assess the relationships between low or high snail population density and soil component. There is positive relation between terrestrial gastropods population and soil calcium content. Organic matter, soil PH and salinity (EC, electric conductivity) with low and high density in all districts were average [(1.2 and 2.9), (7.54 and 9.01) and (1.54 and 4.52)] respectively. It is clearly that Organic matter, soil PH and EC had negative correlation with land gastropods low or high densities. However, the quantitative species composition of the land snail assemblage is related to soil properties to a lower degree than snail density and species richness, and other habitat characteristics such as vegetation can be important for species abundance.

\section{INTRODUCTION}

Mollusks are considered as a group of the most serious pests attacking agriculture crops around the world. They were recorded with a relatively high population density on major economic crops at Dakahlia Governorate (Awad 2000, Mortada 2002, Daoud 2004 and Asran et al., 2011). Economic damage caused by these mollusks is due to feeding and to contamination with their bodies, faces or slime leading to deterioration of the product quality, in addition the financial loss. Few works were dealing with the survey and distribution of land snails species in Kafr ElSheikh Governorate Shalaby et al. (2007), Shahawy, (2013) and Abd Elwahed,(2013). The ecological information are very necessary to plan the successful programs for protection of crops from damage due to land snails. It helps in choosing the suitable integrated land snails management methods. The selection of control methods concept conditions depends on specific composition of the pests, the state and the density of their population Zedan et al., 2006 and Mortada et al., 2012). The main aim of this work is to get more information about survey, population density and relationships between low or high snail population density and soil component in five districts at Kafr El-Sheikh governorate.

\section{MATERIALS AND METHODS}

Survey, population density and chemical soil analysis conducted to obtain basic information concerning aspects of terrestrial snails and slugs infesting fields and vegetables crops as well as ornamental plants in Kafr ELSheikh Governorate.

1. Occurrence of terrestrial gastropods attacking crops at Kafr El-Sheikh Governorate.

Terrestrial gastropods were surveyed in five districts of Kafr El-Sheikh Governorate were showed in Fig (1). i.e. Kafr El-Sheikh, El- Hamol, Desouq, Beiala and Foua. Through the two successive years during the period from September 2015 to August 2016, five localities (villages) were chosen represented of each district. The survey under taken on host plant species including field crops were Egyptian clover, Trifolium axalendrium; broad bean, Vicia faba; wheat, Triticum vulgaris; maize, Zea maize and sugar beet, Beta vulgaris. Vegetable crops were cabbage, Brassica oleracea; lettuce, Lactuca sativa; pea, Pisum sativum; potatoes, Solanum tuberosum and carrot, Daucus carota. The ornamental plants and wood trees were nasturtium Tropaeolum magus; alocasia, Alocasia gigantea; custard, Monestera acuminate; casuarinas, Casuarina equistifolia and caphor, Eucalyptus rostrata. Fruit trees, i.e. grape, Vitis vinifera; guava, Psidium guajava; banana, Musa spp; date palm, Phionex dactlifera and citrus.

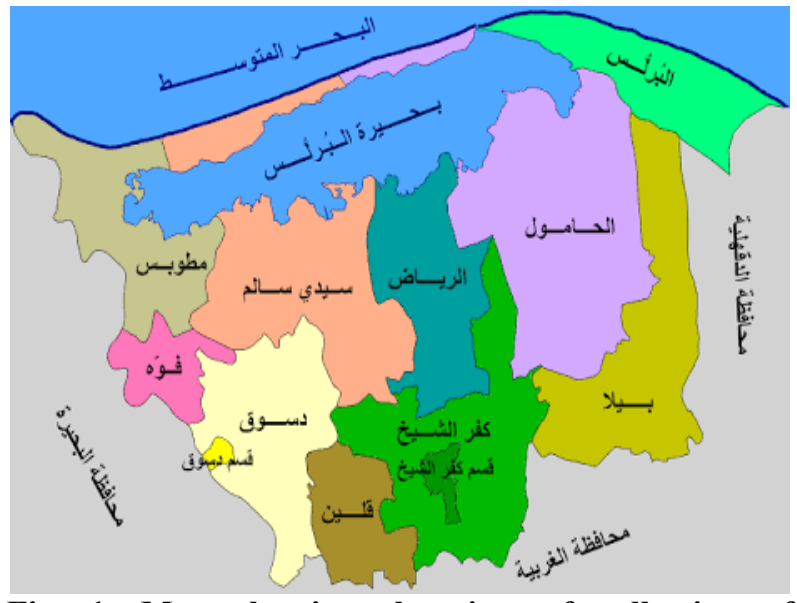

Fig. 1. Map showing the sites of collection of terrestrial gastropods and soil samples in Kafr El-Sheikh Governorate.

One feddan was randomly chosen for each of the tested crop in each locality (village). Ten samples were chosen randomly for each crop in locality $\left(50 \times 50 \mathrm{~cm}^{2}\right.$ each one). The collected land snails and slugs from any tested crop were transported in cloth bags to laboratory and identified on the basis of external features of shell and body of gastropod according to the key given by Godan (1983), Baker (1989), Mortada (2002) and Daoud (2004).

2. Population density of terrestrial gastropods on different host plants at Kafr EL-Sheikh Governorate.

Ten samples of $50 \times 50 \mathrm{~cm} 2$ were chosen randomly from each locality. Samples were taken in early morning in field crops, vegetable, annual ornamental plants and wood trees. All snails and slugs were found on plants or on soil surface of the sample area were counted. In case of samples which were collected from fruit, ornamental and wood trees, mean number of snail was calculated in four areas of one meter under each tree around trunk and on one 
meter height of tree trunk from soil surface reported by Mortada (2002) and Daoud (2004). Examinations occurred early morning. Data concerning the snail population were subjected to statistical analysis using Anova test, Co. hort software program, (2004).

3. Soil samples component and chemical analysis.

Soil samples were taken from five districts, Kafr- El Sheikh Governorate as showed in Fig (1), Kafr El-Sheikh, El- Hamol, Foua, Desouq, and Beiala districts and were air dried, grind and pass through $2 \mathrm{~mm}$ sieve for chemical analysis. Total soluble salts (TSS) were measured as (EC ds m-1) Electrical Conductivity apparatus in the saturated soil paste extract; soluble ions, soluble kations, soil $\mathrm{PH}$ and Organic matter were determined according to Page et al. (1982).

\section{RESULTS AND DISCUSSION}

1. Occurrence and distribution of terrestrial gastropods in Kafr El-Sheikh Governorate.

Terrestrial gastropods (snail and slug) species were subjected to an extensive occurrence survey during the period from September 2015 to August 2016. These pests were infesting field, vegetable crops, ornamental plants and orchards trees in 25 localities (villages) representing five districts (the countries) of Kafr EL-Sheikh Governorate. The surveyed localities were as follows: Five localities (villages) were chosen represented of each district. As illustrated in Tables (1 and 2) and Figs (2 and 3) ten herbivorous species, eight land snails and two slugs species were surveyed, the collected species were represented by one order Stylomatophora, which represented in the present work by three families. The first family was Helicidae which presented by the conical snail, Cochlicella acuta Muller; the brown garden snail, Eobania vermiculata (Müller); the small sand snail Helicella vestalis (Pfeiffer); the glassy clover snail, Monacha cartusiana (Müller); Monacha cantiana (Montagu), Monacha obestructa (Pfeiffer) and Theba pisana . While the second family: Succinidae was presented by two land snails, the small amber snail, Succinea oblonga (Draparnoud) and the amber snail Succinea putris Linnaeus. Finally, the third family was belonging to terrestrial slugs. Limacidae was presented by the field slug Deroceras reticulatum (Müller) and marsh slug Deroceras leave (Müller).
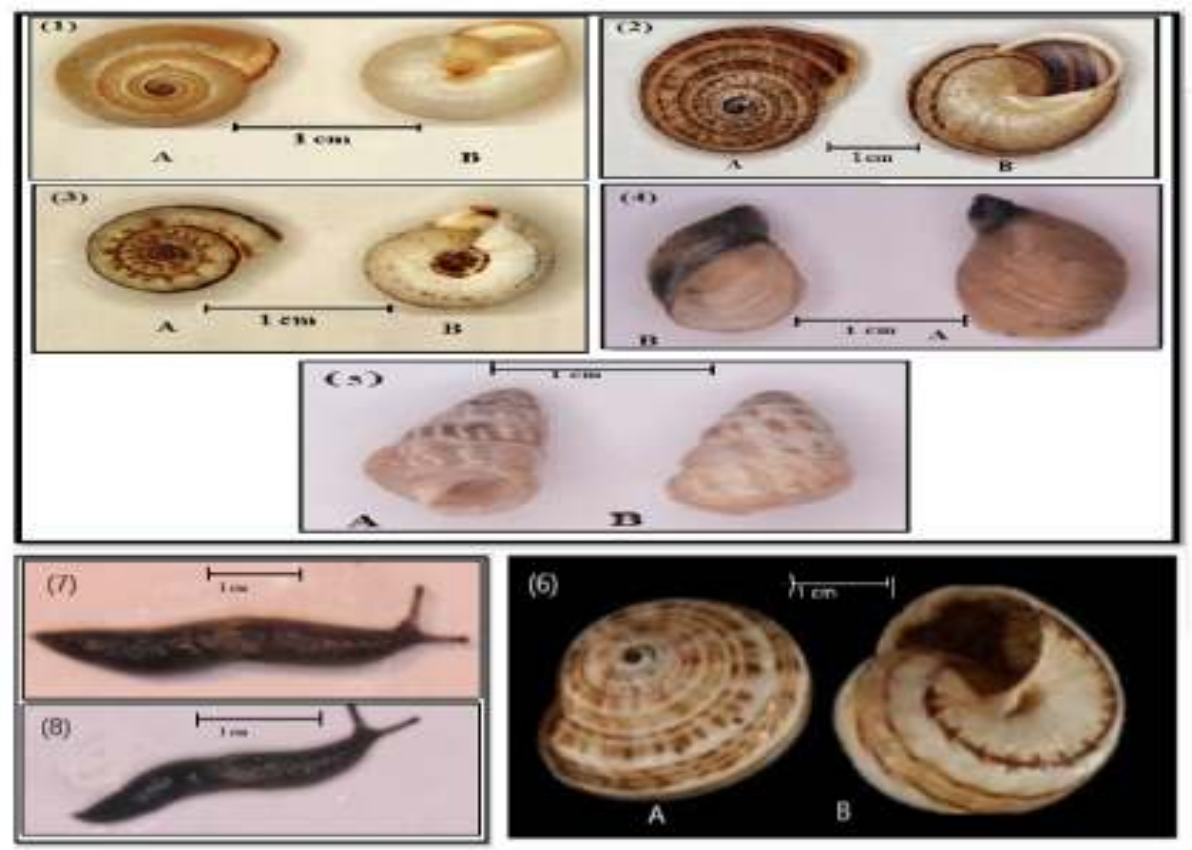

Fig. (2): A,B Dorsal and ventral view of land snail species infesting crops at Kafr El-Shiekh Governorate ; (1)-Monacha sp. (2)-Eobania vermeculata, (3)-Helicella vestalis (4)-Succinea sp. (5) Cochlicella acuta (6)-Theba pisana and Adult slugs (7)-Deroceras reticulatum (8)-Deroceras laeve.

It is clearly shown that the glassy clover snail Monacha species infested all examined plants especially field and vegetable crops. It was found in all collected samples. While the amber snail Succinea species was detected mainly on field, vegetable and fruit trees. It was not found on ornamental plants and wood trees in any districts in Kafr El-Sheikh Governorate. Also, the brown garden snail E. vermiculata, Helicella vestalis and T. pisana was detected mainly on fruit, wood trees and ornamental plants. It was not found on field, vegetable crops.

2. Population density of terrestrial gastropods at Kafr El-Sheikh Governorate.

The population densities of land gastropods on different host plants in five districts at Kafr EL-Sheikh Governorate was illustrated in Figs. $(3,4,5,6)$ as follow: 
Field crops :

The population density of land snails or slugs differed according to host plant and locality, fig (3) indicated that on field crops the highest population densities of Monacha species were determined on Egyptian clover with range of $(37.3-20.1)$ snails per $50 \times 50 \mathrm{~cm}^{2}$. While ranges of population density on broad bean, wheat, sugar beet and maize were (24.1- 9.3), $(12-6.1),(24.1-13.2)$ and (9.4 5.3) snails per sample, respectively. The highest numbers of Succinea sp. were counted on Egyptian clover in Beiala (11.2) and Fouaa (9.1) snail per sample, while the lowest ones were found on broad bean (4.1) snails per sample in El-
Hamol district. Population densities of C. acuta were (8.4) on Egyptian clover and (7.1) snails per sample on broad bean in El-Hamol district. While the lowest one were found on broad bean (3.1) snails per sample in Kafr EL-Shiekh district. The highest numbers of $H$. vestalis were (11.2) and (10.2) snails per sample on Egyptian clover and maize in Desouq district. On the other hand, population densities of D. leave on Egyptian clover in Kafr EL-Shiekh, Beiala and Fouaa were 2.3, 4.1 and 4.1 slugs per sample, respectively. While the highest numbers of $D$. reticulatum slugs were (7.2) and (6.2) slugs per sample on Egyptian clover in Beiala and Fouaa districts.

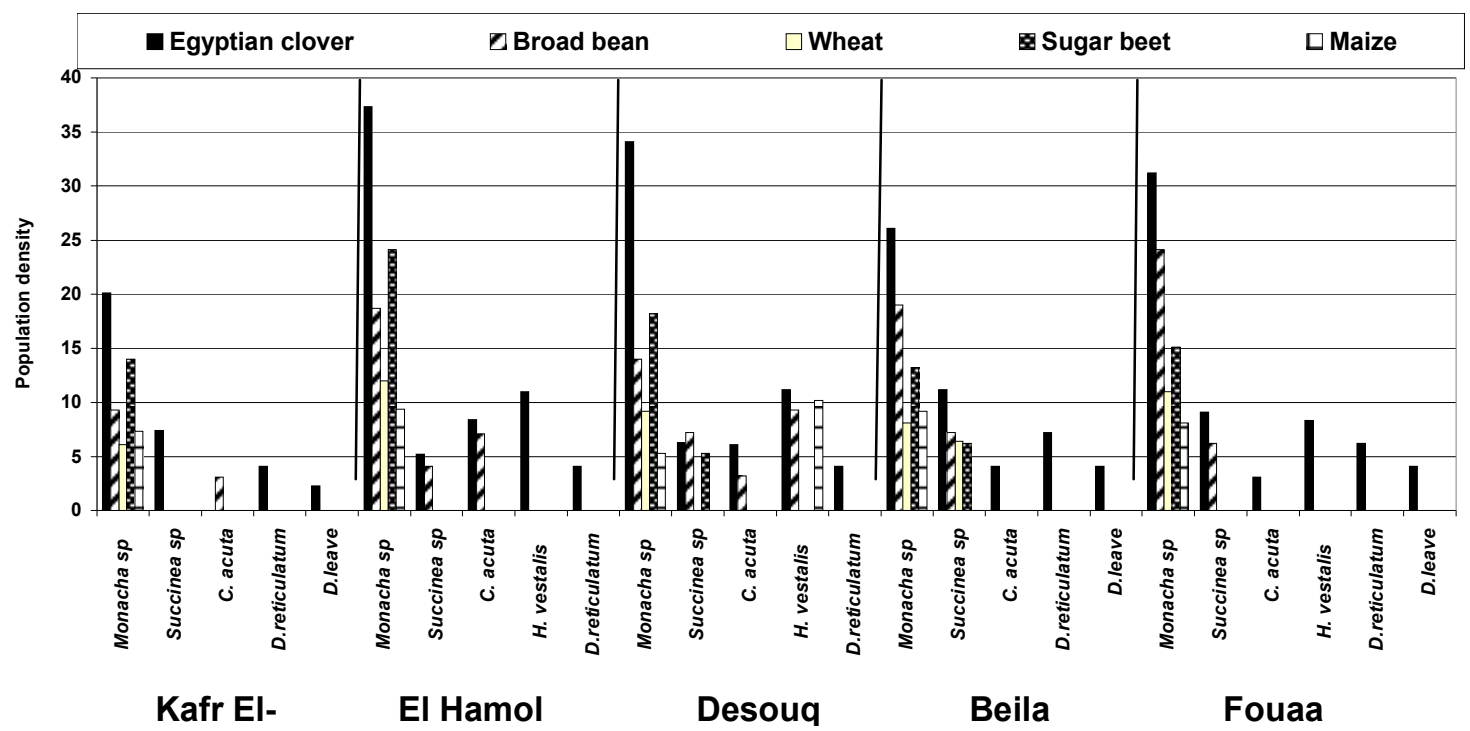

Fig. 3. Population density of some land snail and slugs on field crops in five districts of Kafr El-Sheikh Governorate during season 2015 / 2016.

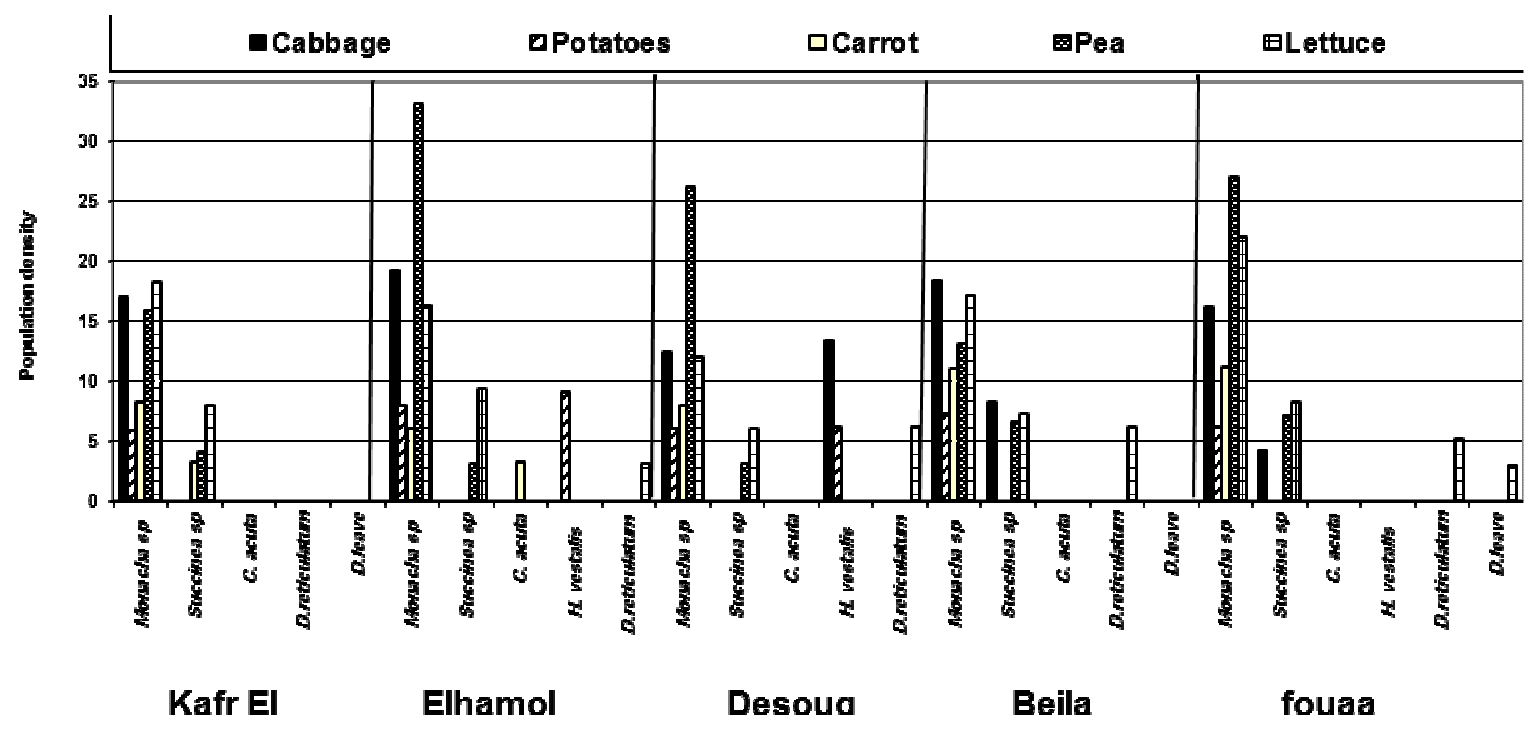

Fig. 4. Population density of some land snail and slugs on vegetable crops in five districts of Kafr El-Sheikh Governorate during season 2015 / 2016.

\section{Vegetable crops:}

Regarding population density of snails and slugs on vegetable crops, fig. (4) indicated that cabbage, potatoes, carrot, pea and lettuce were infested with Monacha sp. in all districts. The population density were found with range of 6 to 33.2 snails per sample. Also, Succinea sp. was counted on lettuce and pea in all districts with range of 3.2 to 9.4 snails per sample. While $C$. acuta and $H$. vestalis were found only on carrot (3.2) and potatoes (9.2) in ELHamol district. Whereas D. reticulatum were found in ELHamol, Desouq, Beiala, Fouaa on lettuce only with population densities of $(3.2,6.2,6.3$ and 5.2 ) slugs per sample, while $D$. leave was detected on lettuce also, with 3 slugs per sample in Foua district . 


\section{Fruit trees:}

Concerning population density of snails and slugs on fruit trees fig. (5), it is obvious that, Monacha sp. Theba pisana and E. vermiculata were the most abundant species with population density ranged (3.1 to 22.3) and (3.1 to 14.3) snails per sample, respectively. The amber snail Succinea sp. was counted on date palm (1.2) and citrus (7.1) snails/sample in Kafr EL-Shiekh district. It was found on citrus only with (6.2) snails/sample in Desouq district.
The highest number population density of $C$. acuta was ranged between (2.1) snails/sample to (13.1) snails/sample on date palm in Beiala district. $H$. vestalis was found on guava (14.1) and banana (11.6) snails/sample in El-Hamol district. Also, it was counted on date palm (2.1) and guava (11.1) snails/sample in Desouq district. On the other hand, D. reticulatum was found in all districts with range 3.1 to 7.1 slugs/sample. While $D$. leave was not found on fruit trees in all districts .

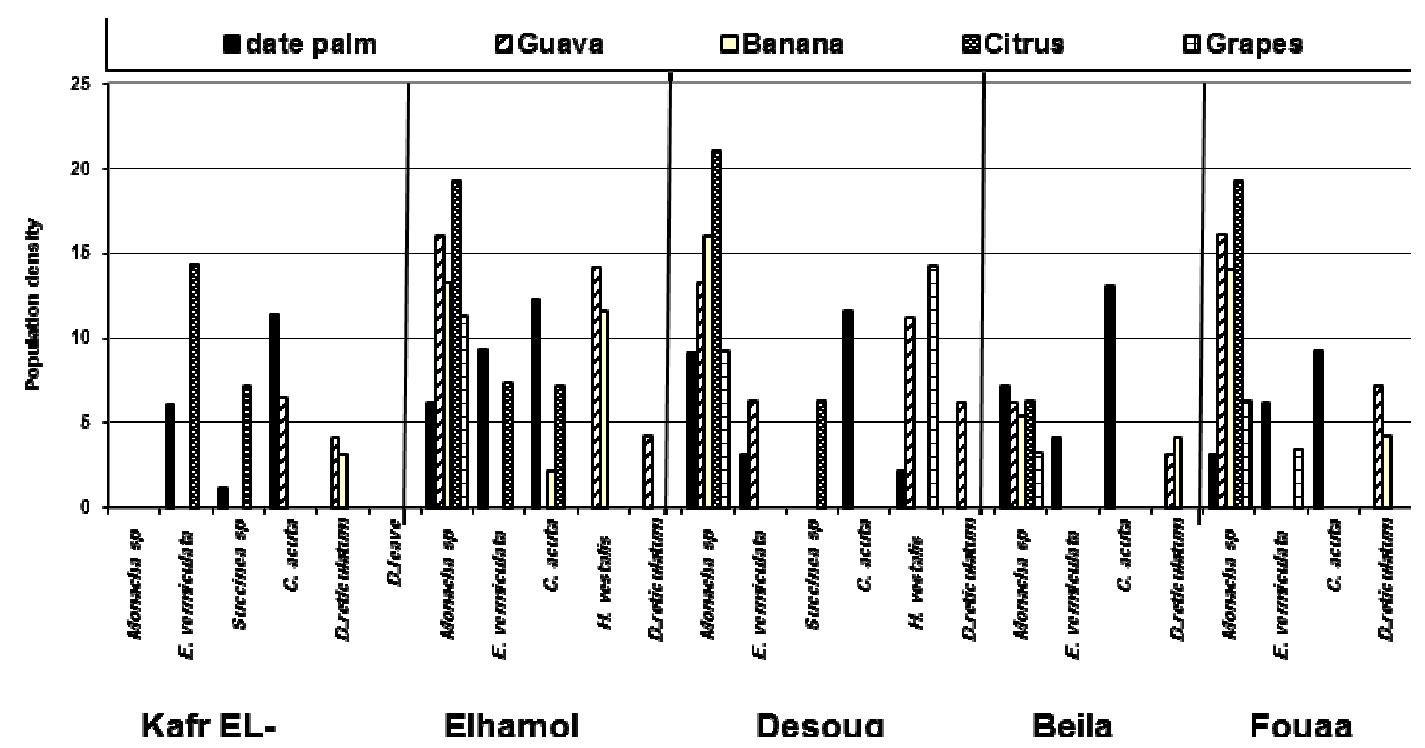

Fig. 5. Population density of some land snail and slugs on fruits in five districts of Kafr El-Sheikh Governorate during season 2015 / 2016.

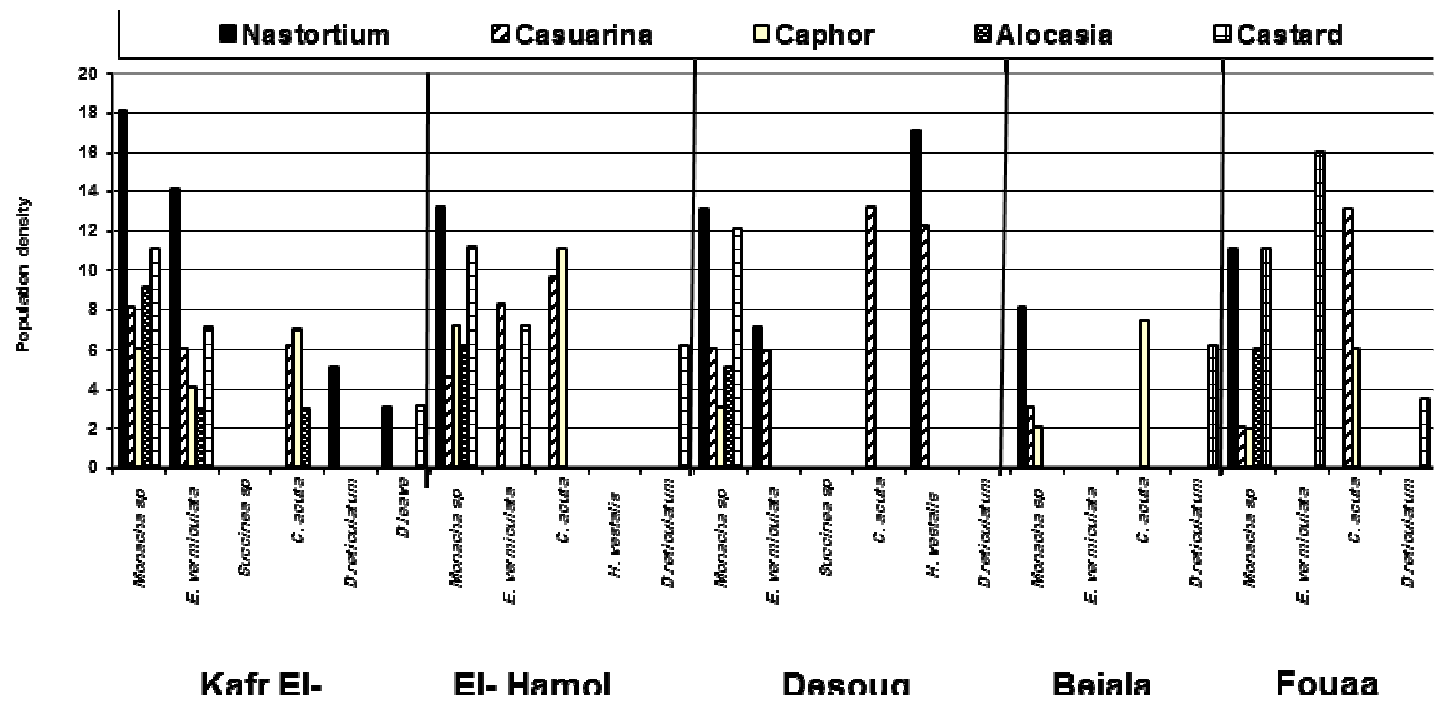

Fig. 6. Population density of some land snail and slugs on ornamental and wood trees crops in five districts of Kafr El-Sheikh Governorate during season 2015 / 2016.

Ornamental plants:

Finally, on ornamental plants and wood trees were shown in fig. (6), Monacha sp. ,Theba pisana and E. vermiculata were the most abundant species with population density ranged between ( 2 to 18.1 ) and ( 3 to 16 ) snails/sample, respectively. Other identified species were recorded on few hosts with a relatively low population density, except $H$. vestalis which was found on nasturtium (17.1) and casuarinas (12.3) snails/sample in Desouq district.
Our results are in agreement with those of El-Deeb et al. (1996) who recorded S. putris and E. vermiculata in fields and orchards of Kafr El-Sheikh. Idress (2003) surveyed the land snails $M$. containa, E. vermiculata, Theba pisana (Muller), C. acuta, S. putris infesting field and vegetable crops, orchards and ornamental plants at El-Hamol, Balteem, Sakha and Kafr El-Sheikh districts. Mortada (2002) found that 13 species of terrestrial snails and slugs belonging to five families Helicidae, 
Succinedae, Achatinidea. Zonitidae and Limacidae were detected on different crops in 25 localities representing five districts of Dakahlia Governorate. Abd El-Aal,(2001) M. cartusiana, H. vestalis, C. acuta, E. vermiculata and Succinea sp. were found infesting major crop in Sharkia Governorate. Al-Akra, (2001) and Hany, (2015). M. cartusiana, E. vermiculata, C. acuta, O. alliarius, D. reticulatum and L.flavus were found in Gharbia and Monufia Governorate.

\section{Soil component and chemical analysis.}

Data in Table (1), showed that chemical analysis of soil component in five districts at Kafr El-Sheikh governorate with low and high land snail densities. Soil samples were taken from five districts to analytical chemically and determined the relationship between low or high snail densities and soil components. Organic matter (O.M), soil $\mathrm{pH}$ and salinity(EC, Electric Conductivity) with low and high density in all districts were average [ (1.2 and 2.9), (7.54 and 9.01) and (1.54 and 4.52)], respectively. It is clearly that O.M, pH and EC had negative correlation with land gastropods low or high densities. Both cations, $\mathrm{Na}, \mathrm{K}$ and $\mathrm{Mg}$ and Anions $\mathrm{Hco}_{3}, \mathrm{Co}_{3}, \mathrm{Cl}$ and $\mathrm{So}_{4}$ were non significant with had negative correlation with densities too in all samples.

Table 1. Soil component chemical analysis and their terrestrial gastropods densities at some Kafr El-Sheikh governorate.

\begin{tabular}{|c|c|c|c|c|c|c|c|c|c|c|c|c|}
\hline \multirow{2}{*}{ District } & \multirow{2}{*}{$\begin{array}{c}\text { gastropod } \\
\text { density }\end{array}$} & \multicolumn{11}{|c|}{ soil content } \\
\hline & & O.M & PH & Ec & $\mathbf{N a}$ & $\mathbf{K}$ & $\mathbf{C a}$ & Mg & $\mathrm{HCo3}$ & $\mathrm{Co3}$ & $\mathbf{C l}$ & So4 \\
\hline Kafr El- & high & 1.77 & 8.82 & 14.19 & 72.5 & 1.59 & 43.75 & 2.5 & 2.5 & 0 & 106.25 & 34.09 \\
\hline Sheikh & law & 1.85 & 8.39 & 3.85 & 15.63 & 0.88 & 13.75 & 8.13 & 1.88 & 0 & 10.0 & 26.5 \\
\hline \multirow{2}{*}{ El -Hamol } & high & 1.39 & 8.10 & 1.85 & 6.75 & 0.69 & 6.88 & 4.38 & 1.88 & 0 & 5.63 & 11.19 \\
\hline & law & 1.42 & 7.68 & 1.54 & 4.06 & 1.88 & 5.63 & 3.75 & 1.25 & 0 & 3.75 & 10.31 \\
\hline \multirow{2}{*}{ Desouq } & high & 1.33 & 8.27 & 1.89 & 46.88 & 5.66 & 43.13 & 23.75 & 1.88 & 0 & 93.75 & 23.78 \\
\hline & law & 2.90 & 7.90 & 17.44 & 3.79 & 3.79 & 36.25 & 24.38 & 5.63 & 0 & 125 & 43.79 \\
\hline \multirow{2}{*}{ Beilaa } & high & 1.33 & 8.02 & 4.49 & 2.13 & 2.13 & 19.38 & 8.15 & 2.5 & 0 & 24.38 & 18.01 \\
\hline & law & 1.2 & 9.01 & 3.54 & 3.45 & 3.22 & 11.03 & 4.12 & 1.13 & 0 & 6.88 & 10.01 \\
\hline \multirow{2}{*}{ Foua } & high & 1.48 & 7.54 & 2.68 & 4.72 & 2.25 & 2.12 & 3.28 & 2.4 & 0 & 4.73 & 6.68 \\
\hline & law & 1.37 & 8.13 & 4.52 & 6.14 & 5.18 & 2.2 & 2.98 & 4.2 & 0 & 12.81 & 8.25 \\
\hline
\end{tabular}

O. $\mathrm{M}=$ organic matter $, \mathrm{PH}, \mathrm{EC}=$ salinity

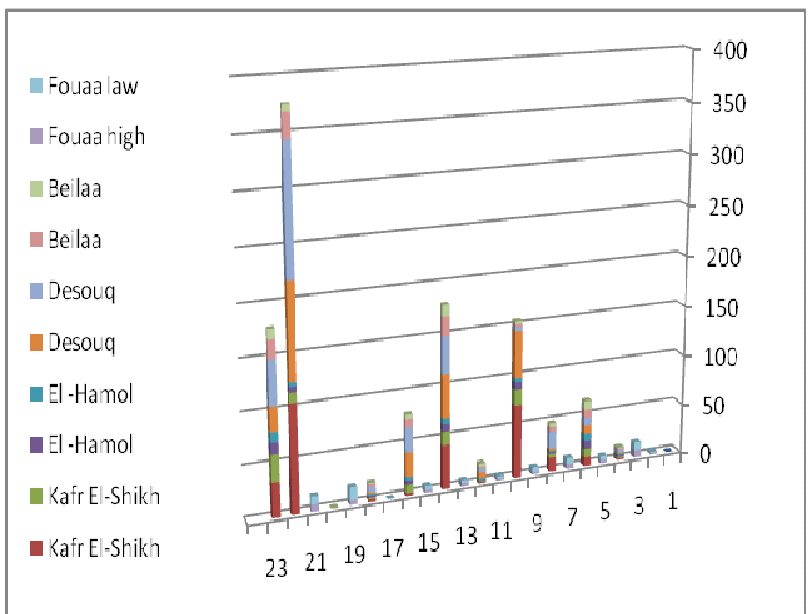

Fig. 8. Chemical analysis of soil components related with terrestrial gastropods densities .
Correlation coefficient between soil Ca component and population density of terrestrial snail in Kafr EL-Sheikh governorate were illustrated in Table (2), which showed high population density in districts Kafr EL-Sheikh, EL-Hamol, Desouq, Beila and Foua were (153.92, 137.22, 134.03, 155.68 and 128.97) snail $/ \mathrm{m}^{2}$ and $\mathrm{Ca}$ content in these sites $(43.75,16.88,43.13,91.38$ and 12.2) mole/g soil.

It is clear that the relationship between $\mathrm{Ca}$ content and high population density are positive correlation $(\mathrm{P}$. Factor $=0.785)$. On the other hand, low population density in the aforementioned districts were $(48.19, \quad 40.92, \quad 34.05, \quad 31.2$ and 43.78$) \quad \mathrm{snail} / \mathrm{m}^{2}$ respectively and $\mathrm{Ca}$ content in its sites were $(13.75$, $5.63,32.25,11.03$, and 2.4$) \mathrm{mole} / \mathrm{g}$ soil respectively. The correlation were negative $(\mathrm{P}$. Factor $=-0.432)$ between population density and $\mathrm{Ca}$ soil content.

Table 2. Correlation coefficient between soil Ca content and population density of terrestrial snails gastropods in Kafr El-Sheikh governorate.

\begin{tabular}{lcccccc}
\hline parameters & Kafr El-Sheikh & El-Hamol & Desouq & Beila & Foua & Pearson's Factor. \\
\hline High Population density & 153.92 & 137.22 & 134.03 & 155.68 & 128.97 & $0.785^{* *}$ \\
High Ca content & 43.75 & 16.88 & 43.13 & 91.38 & 12.2 & -0.432 \\
Low population density & 48.19 & 40.92 & 34.05 & 31.2 & 43.78 & -2.4 \\
Low Ca content & 13.75 & 5.63 & 32.25 & 11.03 & 2.4 & - \\
\hline
\end{tabular}

** Correlation is significant at level 0.05

Various terrestrial gastropods infested all crops in the five districts with low or high population density not attempt to soil components [ EC, Soil pH, O.M, Kations $(\mathrm{Na}, \mathrm{K}$ and $\mathrm{Mg})$ and anions $\left(\mathrm{Co}_{3}, \mathrm{Cl}, \mathrm{HCo}_{3}\right.$ and $\mathrm{So}_{4}$ ) ] except $\mathrm{Ca}$ soil content.

Discussing these results indicated that population density of land snails and slugs had correlation with $\mathrm{Ca}$ soil content. The population density were increased in high $\mathrm{Ca}$ soil content places in addition to some climatic factors such as soil moisture, plant covering, relative humidity and moderate temperature (Winter and Spring months). Our results agree with Miller and Waite (1999) that found that no correlation between soil $\mathrm{pH}$ and snail density according to their study in 13 sites in England. 
Hany, (2015), most of land gastropods were observed during winter and spring months due to the suitable climatic condition i.e suitable soil moisture, relative humidity and temperate temperature) compared with other periods.

\section{REFERENCES}

Abd -El-Aal, S.M. (2001). Studies on certain land snails at Sharkia Governorate. M. Sc. thesis, fac. Agric. Zagazig Univ., 137pp.

Abd- El-Wahed, S. I (2013). Biological and pathological studies on some land snail species and their control at Kafer El-Sheikh governorate. M Sc. Thesis, Fac. of sci, Tanta Univ., 168 p

Al-Akra, T.M. (2001). Ecological, biological and toxicological studies on some mollusca species at Monufia and Garbia Governorate. M.Sc. Thesis, Fac. Agric, AL-Azhar Univ., 189 pp.

Anova,Cohort software: (2004): Costat. (www. Cohort. Com. Montery, California, USA).

Asran, A.A.; T.M.S. Keshta; M.M. Mortada and F. K. Khider (2011). Influence of climatic factors on population density of land snails infesting some crops and their damage quessna district (Minufya Governorate ). J. plant port. and pathology ,Mansoura Univ., vol. 2(4): 501-508.

Awad, M. H. (2000). Molluscs Morphology of NileDelta. Ph. D. thesis, Fac. Agric. Mansoura Univ., 190PP.

Baker G. H. (1989). Damage, population dynamics, movement and control of pest Helicid snails in southern Australia. Monograph, British crop protection Council. No. 41: 175 - 185 .

Daoud, M. E. A. (2004) Ecological and morphplogical studies on some terrestrial snail in Dakahlia Governorate. M. Sc. thesis Fac. Agric. AL-Azhar Univ., 170p.

El-Deeb, H. I.; E. M. Ghamry; N. El-Hwashy and N. Essa (1996). Relative abudance of some land snails in certain Governorate of Egypt. J. Agric. Sci. Mansoura Univ., 21(8): 2977-2982.

Godan, D. (1983). Pest slugs and snails, Biology and control. Springer Verlag, Berlin 424 PP.
Hany, H. (2015). Biological aspects and population dynamics of three terrestrial snails infesting fruit trees in Egypt. Eco. Ento. Agri. Zool. Dep. Fac. Of Agric., Monoufia Univ. Egypt Int. J. Adv. Res. Biol. Sci. 2(1): $169-180$.

Idress, N.M.M. (2003). Application of some environmental safe methods for population management of common land snails in the newly reclaimed land in Egypt. M.Sc. Thesis, Environ., Stud. Res., Institute Ain shams Univ., 150 PP.

Millar, A. J. and Waite, S. (1999)Molluscs in coppice woodland J. of Conchology. 36, 25-48.

Mortada, M. M.(2002). Ecological and biolodical studies on certain terrestrial Gastropods in Dakahlia governorate. phD. thesis Fac. Agric. Zagazig Univ., 185pp.

Mortada, M. M.; A. A. M. Mourad; A. M. Abo-Hashem and T. M. S. Keshta. (2012): Land snails attacking pea fields: 1- Efficiency of certain biocides and molluscicides against Monacha sp. Land snails at Dakahlia Governorates. J. Plant Prot., and Path., Mansuora Univ., Vol. 3 (7): 717 -723 .

Shalaby, G.A.; M. M. Mortada and A. M Soliman. (2007). Land snail attacking sugar beet fields: population density, Damage and losses caused by Monacha cantiana snails at Kafr EL-sheikh Governorate. J. Agric. Sci. Mansoura Univ., 32(4): 3179-3183.

Shahawy, A.W (2013). Population density and food preference of the land snail, Monacha cantiana (Montagu) to cucurbit vegetable crops and using plant extracts for its control J. Plant Prot., and Path., Mansoura Univ., Vol. 4(11):621-627.

Page, A.L.; R. H. Miller and D.R. Keeney (1982). Methods of soil analysis.

Zedan, H. A. Mortada, M. M. and Shoeib, A. Amira. (2006). Assessment of mollucicidal activity of certain pestcides against two land snails under laboratory and field circumstances at Dakahlia Governorate. J. Agric. Sci. Mansoura Univ., 31(6): 3957-3962.

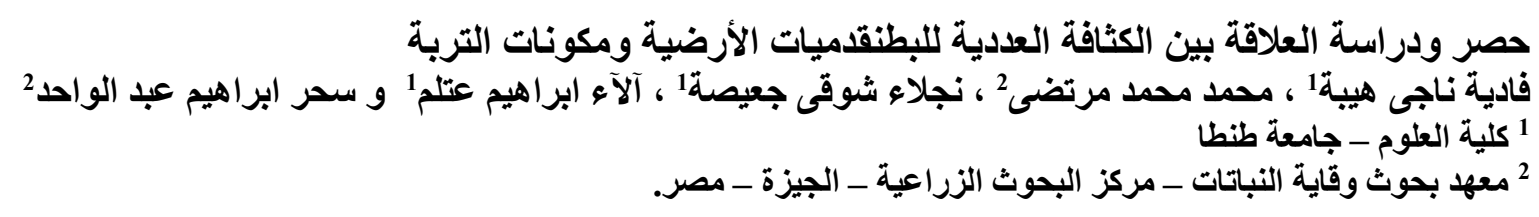

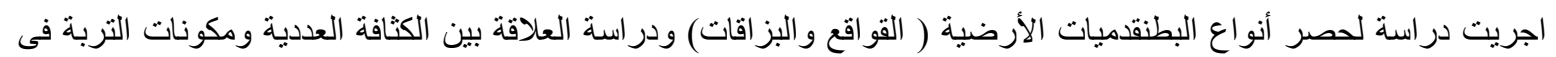

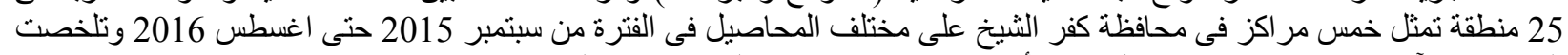

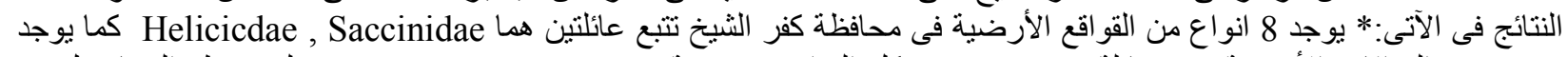

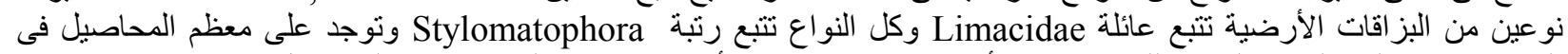

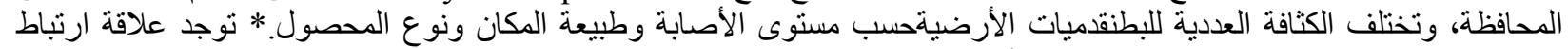

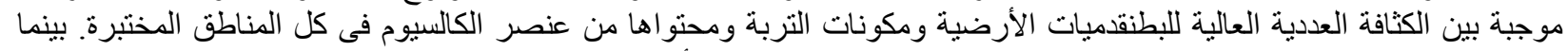

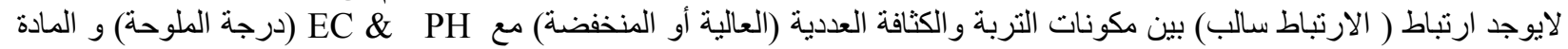
العضوية وباقى المكونات للتربة. 